\title{
Study of Diagenesis and Pore Evolution of Triassic Jialingjiang Formation in Southern Puguang Gasfield
}

\author{
Qi Chen, ${ }^{1,2}$ Quan-wen Liu, ${ }^{2}$ and Shenjian Wang ${ }^{2}$ \\ ${ }^{1}$ State Key Laboratory of Oil and Gas Reservoir Geology and Exploitation, Southwest Petroleum University, \\ Chengdu, Sichuan 610500, China \\ ${ }^{2}$ Guangdong University of Petrochemical Technology, Guangdong, Maoming 525000, China
}

Correspondence should be addressed to Quan-wen Liu; lqw005533@163.com

Received 5 April 2016; Revised 31 May 2016; Accepted 29 June 2016

Academic Editor: Bruno Capaccioni

Copyright (C) 2016 Qi Chen et al. This is an open access article distributed under the Creative Commons Attribution License, which permits unrestricted use, distribution, and reproduction in any medium, provided the original work is properly cited.

\begin{abstract}
The second member of Jialingjiang formation is considered to be an important gas reservoir with good exploration prospects in the southern Puguang gasfield. The diagenesis types are analyzed and different diagenetic stages are divided by analyzing carbon and oxygen isotopes as well as observing the slices. The widespread forms of diagenesis in the research area principally include compaction, cementation, pressure solution, dolomitization, recrystallization, dissolution, and tectonic disruption, among which cementation, dissolution, dolomitization, and recrystallization contribute greatly to the development of porosity in the reservoir. The reservoir has experienced four diagenetic stages: syndiagenetic stage, early stage of diagenesis, diagenetic stage, and late diagenetic stage. Most of the primary pores were destroyed in the diagenetic evolution stages of reservoir; the present porosity mainly belongs to the secondary pores.
\end{abstract}

\section{Introduction}

Puguang gasfield is located in the northeast of Sichuan basin and considered the largest gasfield in the marine carbonate environment in China. Permian Changxing and Triassic Feixianguan formations are the main dolomite reservoir forming layers $[1,2]$ with characteristics of large thickness and good physical properties.

With the development of exploration and research, geologists have gradually realized that the lower Triassic Jialingjiang formation has developed a good dolomite reservoir and could also be considered as a key exploration target. Jia2 members are formed in the shallow sea with thicknesses of $168 \mathrm{~m}$ to $215 \mathrm{~m}$ (Figure 1). Their lithology, which consists of argillaceous limestone, dolomite, and gypsum rocks, is dominated by algal dolomite and doloarenite. As for a typical low porosity and low permeability reservoir, there is strong heterogeneity, rock porosity is between $1.96 \%$ and $4.2 \%$, and permeability is generally less than $10 \mathrm{mD}$. Diagenesis has great influence on the pore evolution and transformation of the reservoir, especially dolomitization, compaction, pressure solution, and cementation [3-5].

\section{Types of Diagenesis}

Carbonate diagenesis includes the processes that occur between the deposit formation and initial metamorphism under high temperature and pressure, including the ones such as cementation, dolomitization, and dissolution. It also includes some microscopic processes such as the development of micropores, trace element migration, and stable isotope variation.

While cementation, compaction, and pressure solution have a negative influence on reservoir porosity and recrystallization and metasomatism have little effect on the physical properties of the reservoir, dolomitization, dissolution, and tectonic rupture are the main processes that improve the reservoir properties and also the major influencing factors on the carbonate reservoir pore spaces of Jia-2 member in southern Puguang gasfield.

2.1. Cementation. Cementation comprises processes leading to the precipitation of minerals in primary or secondary pores and requires the supersaturation of pore fluids with respect to the mineral. It is a very significant factor in diagenesis and 


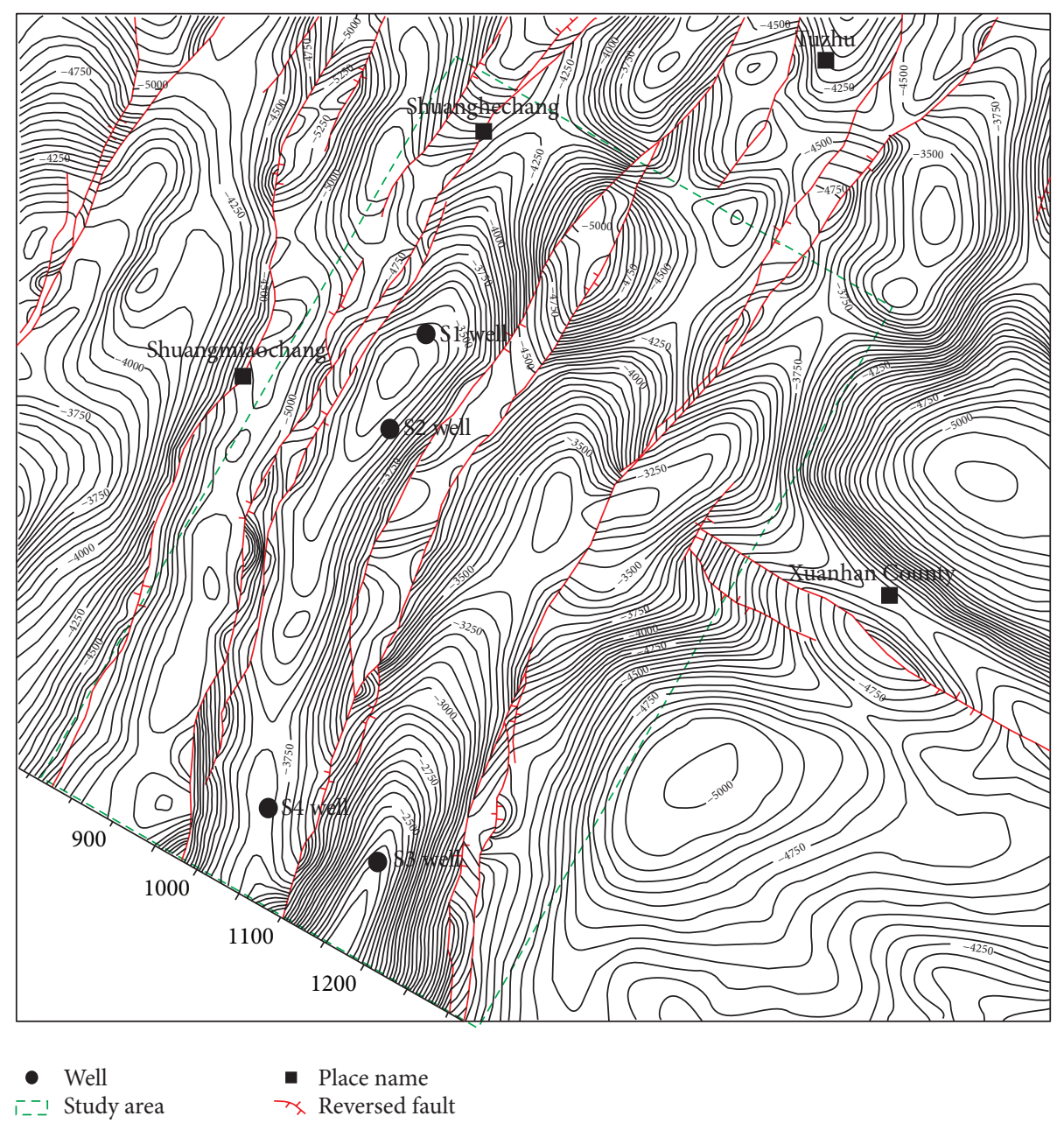

FIGURE 1: The Jia-2 formation of the top surface structure of the study area.

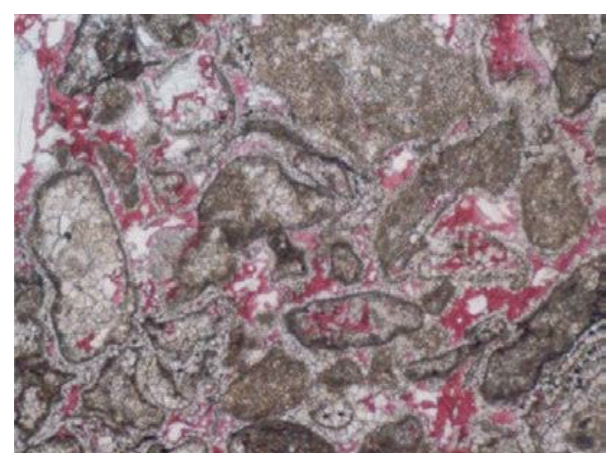

Figure 2: Silty dolarenite, S2, 2355.04 2355.65 m, $\mathrm{T}_{1} \mathrm{j}^{2}$.

is a form of destructive diagenesis, with the early diagenetic cementation leading to reduced primary porosity.

Based on the calcite cement structure from the core slice, the cementation of Jia- 2 member is divided into three stages.

The primary pores and the early dissolution pores were all filled during early cementation and the cement is mainly of fibrous or foliaceous types (Figure 2). A comparison of the morphological characteristics of calcite cementation of carbonate rocks in different diagenetic environments showed this kind of cement to be the main diagenetic feature in the syngenesis-marine environment.

In the fine-grained calcite cement, generally produced from the fillings in the interstices among carbonate grains, the calcite surface is comparatively clean and calcite crystals gradually become thicker from the grains to the center of the interstices (Figure 3). This type of cementation is closely related to the presence of atmospheric water; it is assumed that the cement might be produced due to the cementation of the atmospheric water before burial and compaction processes.

The late cementation and filling mainly show the filling of the early corrosion holes and tectonic fissures in dolomite grains and the cementation of some intercrystalline dissolution pores. Therefore, it is possible to conclude that the cement is a diagenetic product.

2.2. Compaction and Pressure Solution. The compaction of carbonate rocks in Jia-2 member of the southern Puguang gasfield is different; while some areas are strong, others 


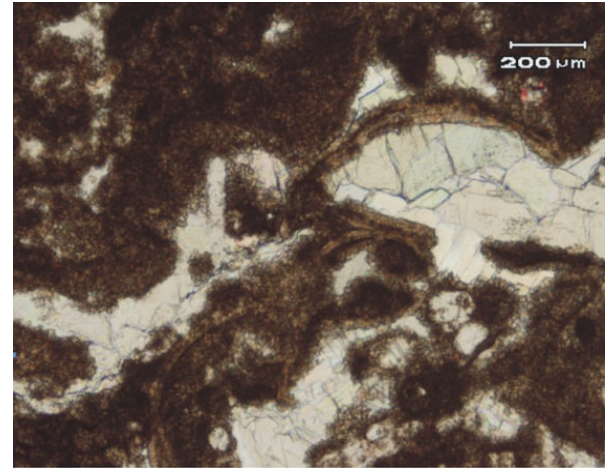

Figure 3: Gypseous dolarenite, S1, 3575.24 3575.56 m, $\mathrm{T}_{1} \mathrm{j}^{2}$.

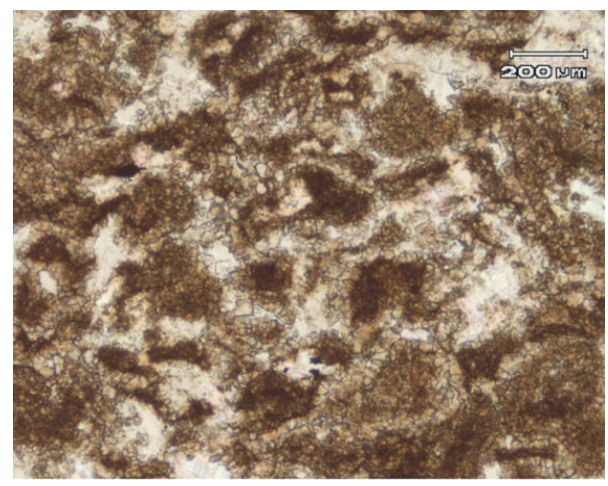

Figure 4: Dolarenite, S1, 3585.04 3585.16 $\mathrm{m}, \mathrm{T}_{1} \mathrm{j}^{2}$.

are feeble, which might be related to the difference in the sedimentary fabric of the carbonate rocks. In the strongly compacted areas, the carbonate particles are generally similar to lenticular and augen (Figures 4 and 5).

The occurrence of pressure solution is a very common phenomenon in carbonate rocks, and it always develops in the rocks with significantly different sedimentary structures. The dissolution products formed by pressure solution provide a source for cementation and filling in other locations. Stylolite is a direct evidence of pressure solution. The process of pressure solution in Jia-2 member of the southern Puguang gasfield is quite developed, which is mainly embodied in the form of developed stylolite. While the microfabric on the two sides of stylolite is clearly different, it exhibits uniformity on the same side.

2.3. Dolomitization. Dolomitization in Jia-2 member is the most significant type of diagenesis. A characteristic analysis of dolomite grains and geological conditions shows that penecontemporaneous dolomite may also have different development patterns [6-8].

Most of the dolomite muds, in which parallel laminae, bird's-eyes, and mud plates are developed, rarely contain fossils (Figures 6 and 7). Based on the low degree of order and enrichment of the carbon and oxygen heavier isotopes, two kinds of genetic models of dolomite were put forward

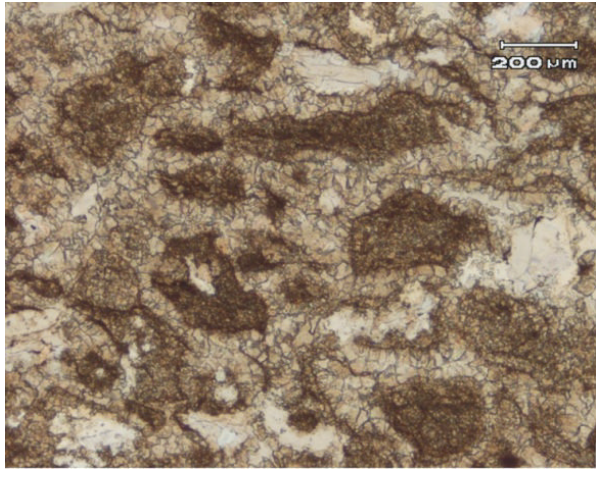

FIgURE 5: Dolarenite, S2, 3655.65 3655.84 $\mathrm{m}, \mathrm{T}_{1} \mathrm{j}^{2}$.

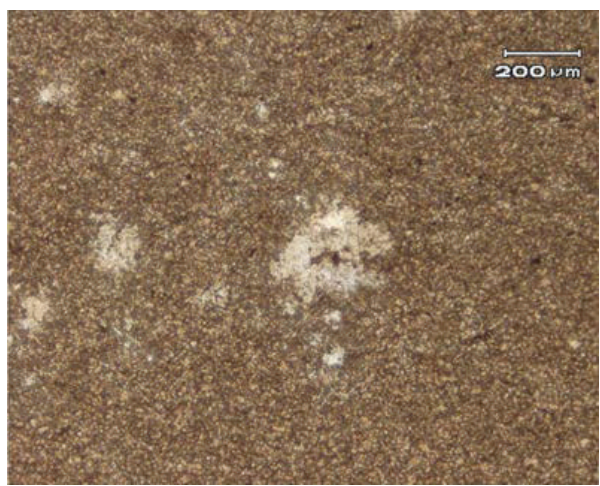

FIGURE 6: Dolomicrite: bird's-eyes were filled with calcite or gypsum, S1, 3571.8 3572.1 m, $\mathrm{T}_{1} \mathrm{j}^{2}$.

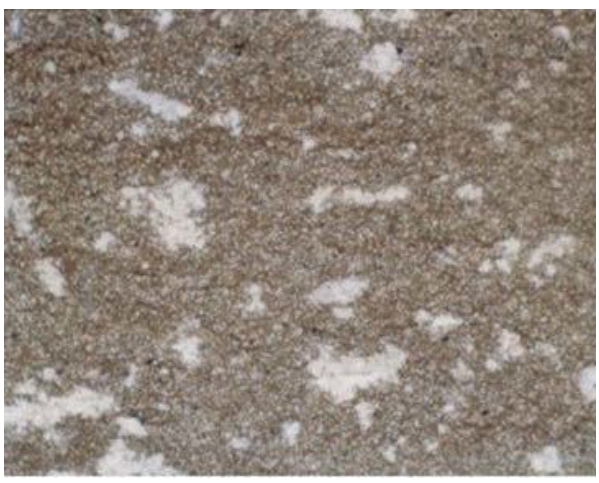

FIGURE 7: Gypseous dolomicrite: bird's-eyes were filled with gypsum, S1, 3586.79 3586.95 $\mathrm{m}, \mathrm{T}_{1} \mathrm{j}^{2}$.

for the study area, that is, capillary concentration model and evaporative pumping model (Figure 8).

Many geological data records have shown that the Jialingjiang formation developed gypsum-salt layers with different thicknesses, which means that the formation continued to develop intermittently under high salinity and evaporative environments. The high $\mathrm{Mg} / \mathrm{Ca}$ ratio and $\mathrm{Mg}^{2+}$-rich hypersaline fluids permeated into the underlying carbonate sediments, and the impact of seepage reflux also promoted the formation of carbonate sediments (Figure 9). The dissolution 
TABLE 1: Carbon and oxygen isotopic sampling data for carbonate rocks.

\begin{tabular}{|c|c|c|c|c|c|c|}
\hline Order & Sample description & Well & Layers & Depth (m) & $\begin{array}{c}\delta^{13} \mathrm{C} \\
\operatorname{PDB}(\% o)\end{array}$ & $\begin{array}{c}\delta^{18} \mathrm{O} \\
\mathrm{PDB}(\%)\end{array}$ \\
\hline 1 & Dolomicrite & S1 & $\mathrm{T}_{1} \mathrm{j}^{2}$ & $3568.89-3568.93$ & 1.62 & -3.66 \\
\hline 2 & Calcareous dolarenite & S1 & $\mathrm{T}_{1} \mathrm{j}^{2}$ & $3571.51-3571.56$ & 0.84 & -3.92 \\
\hline 3 & Gypseous dolomicrite & S1 & $\mathrm{T}_{1} \mathrm{j}^{2}$ & $3571.8-3572.1$ & -0.58 & -3.71 \\
\hline 4 & Argillaceous gypsodolomite & S1 & $\mathrm{T}_{1} \mathrm{j}^{2}$ & $3576.9-3577$ & 4.77 & -3.12 \\
\hline 5 & Globular dolomite & S1 & $\mathrm{T}_{1} \mathrm{j}^{2}$ & $3580.7-3580.26$ & 4.54 & -2.62 \\
\hline 6 & Gypsodolomite & S1 & $\mathrm{T}_{1} \mathrm{j}^{2}$ & $3583.1-3583.21$ & 4.88 & -3.02 \\
\hline 7 & Gypseous dolarenite & S1 & $\mathrm{T}_{1} \mathrm{j}^{2}$ & $3585.04-3585.16$ & 4.88 & -3.37 \\
\hline 8 & Dolarenite & $\mathrm{S} 1$ & $\mathrm{~T}_{1} \mathrm{j}^{2}$ & $3586.58-3586.76$ & 5.12 & -4.33 \\
\hline 9 & Gypseous dolomicrite & $\mathrm{S} 1$ & $\mathrm{~T}_{1} \mathrm{j}^{2}$ & $3586.79-3586.95$ & 4.34 & -4.35 \\
\hline 10 & Fine silty dolomite & S2 & $\mathrm{T}_{1} \mathrm{j}^{2}$ & $3648.94-3649.23$ & 1.47 & -5.78 \\
\hline 11 & Fine silty dolomite & S2 & $\mathrm{T}_{1} \mathrm{j}^{2}$ & $3651.19-3651.43$ & 1.55 & -2.62 \\
\hline 12 & Fine silty gypsodolomite & S2 & $\mathrm{T}_{1} \mathrm{j}^{2}$ & $3654.96-3655.12$ & 4.93 & -2.79 \\
\hline 13 & Gypsodolomite & S2 & $\mathrm{T}_{1} \mathrm{j}^{2}$ & $3666.35-3666.44$ & 6.2 & -4.43 \\
\hline 14 & Fine silty dolomite & S3 & $\mathrm{T}_{1} \mathrm{j}^{2}$ & $2364.6-2364.66$ & 3.67 & -5.22 \\
\hline 15 & Fine silty dolarenite & S3 & $\mathrm{T}_{1} \mathrm{j}^{2}$ & $2366.53-2366.65$ & -0.81 & -3.43 \\
\hline 16 & Calcite dolomite & S3 & $\mathrm{T}_{1} \mathrm{j}^{2}$ & $2374.15-2374.23$ & 1.57 & -3.88 \\
\hline 17 & Calcite dolomite & S3 & $\mathrm{T}_{1} \mathrm{j}^{2}$ & $2378.64-2378.75$ & 0.28 & -5.15 \\
\hline 18 & Microspar dolarenite & S3 & $\mathrm{T}_{1} \mathrm{j}^{2}$ & $2378.75-2379.1$ & -3.18 & -5.35 \\
\hline 19 & Gypsodolomite & S4 & $\mathrm{T}_{1} \mathrm{j}^{2}$ & $3827.79-3827.89$ & 3.15 & -2.61 \\
\hline 20 & Sparry gypsodolomite & S4 & $\mathrm{T}_{1} \mathrm{j}^{2}$ & $3828.22-3828.35$ & 4.12 & -2.88 \\
\hline 21 & Granular gypsodolomite & S4 & $\mathrm{T}_{1} \mathrm{j}^{2}$ & $3828.85-3828.96$ & 4.25 & -2.78 \\
\hline 22 & Fine silty gypsodolomite & S4 & $\mathrm{T}_{1} \mathrm{j}^{2}$ & $3830.45-3830.58$ & 4.68 & -5.32 \\
\hline 23 & Laminated fine silty dolomite & S4 & $\mathrm{T}_{1} \mathrm{j}^{2}$ & $3831.6-3831.72$ & 5.22 & -3.56 \\
\hline 24 & Fine silty dolomite & S4 & $\mathrm{T}_{1} \mathrm{j}^{2}$ & $3832.52-3832.64$ & 5.32 & -3.87 \\
\hline
\end{tabular}

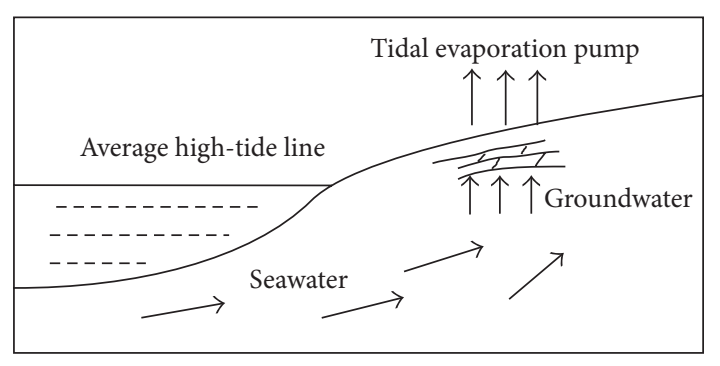

FIGURE 8: The mechanism of evaporation pump.

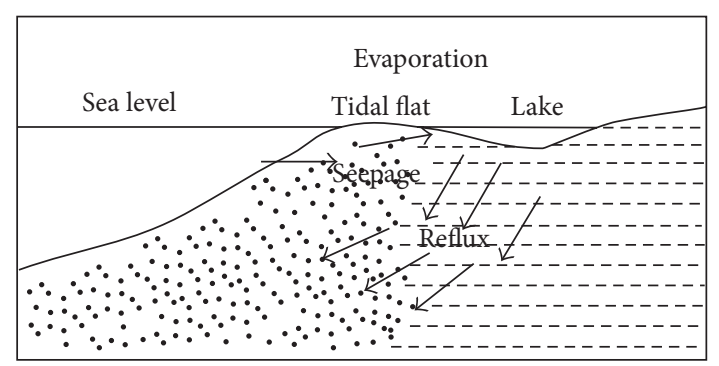

FIGURE 9: The mechanism of seepage reflux. of dolomite grains and dolomitization in the high porosity layers of the grain bank are related to the mixed action of water, which can explain the development of the mixed dolomitization [9].

Oxygen and carbon isotope analyses were carried out on the dolomite with different fabrics in Jia-2 member. According to the basic principles of carbon and oxygen isotopes and the corresponding data (Table 1), the factors that controlled the sedimentary and diagenetic environment of dolomite sediments were analyzed.

(a) General Characteristics. Usually, the original $\delta^{18} \mathrm{O}$ and $\delta^{13} \mathrm{C}(\%)$ values of seawater are relatively large with abundant heavy oxygen and heavy carbon isotope contents, while the $\delta^{18} \mathrm{O}$ and $\delta^{13} \mathrm{C}$ values of evaporate rocks (dolomite, gypsum) are even larger. The fluid system affected by fresh water and $\delta^{18} \mathrm{O}$ and $\delta^{13} \mathrm{C}$ values of its minerals is relatively low and the values vary in a large range.

Based on the drilling data from south Puguang gasfield, the $\delta^{18} \mathrm{O}$ and $\delta^{13} \mathrm{C}(\% 0)$ isotopes have abundant heavy oxygen and heavy carbon content and show the average values of $\delta^{18} \mathrm{O}$ and $\delta^{13} \mathrm{C}$ as $-3.82 \%$ and $2.96 \%$, respectively. The values of oxygen and carbon isotopes are moderately concentrated. Oxygen isotopic values vary from $-5.78 \%$ o to $-2.61 \%$, and carbon isotopic values range from $-3.18 \%$ o to $-5.32 \%$ o (Figure 10 ). 
TABLE 2: Relationship between carbon and oxygen isotopic and sedimentary environment.

\begin{tabular}{lccccc}
\hline & $\begin{array}{c}\text { Grain } \\
\text { dolomite }\end{array}$ & Dolomicrite & Gypsodolomite & $\begin{array}{c}\text { Calcite } \\
\text { dolomite }\end{array}$ & Gypsum limestone \\
\hline$\delta^{13} \mathrm{C}(\mathrm{PDB}, \%)$ & 1.02 & 1.91 & 2.25 & 1.59 & 2.58 \\
$\delta^{18} \mathrm{O}(\mathrm{PDB}, \%)$ & -3.92 & -4.2 & -3.6 & -4.67 & -4.62 \\
Depositional environment & Intertidal flat & Tidal flat & Tidal flat & Tidal flat & Tidal flat \\
Dolomitization & Mixed water & Seepage reflux & Evaporating pumping & & \\
\hline
\end{tabular}

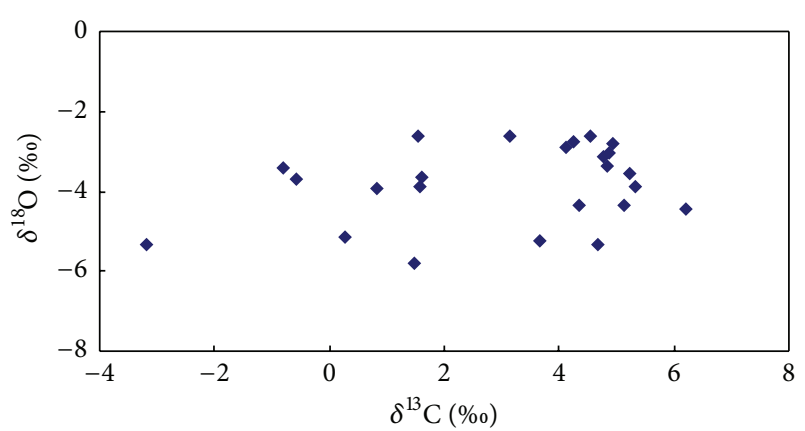

Figure 10: The distribution of oxygen and carbon isotope.

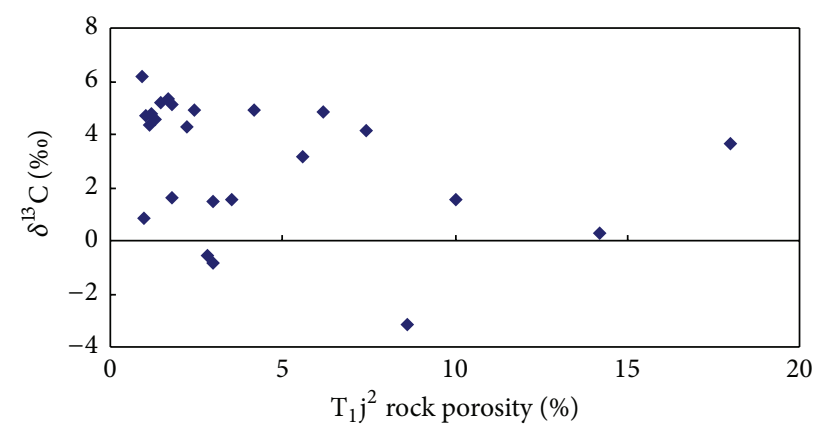

FIGURE 11: Relationship between carbon isotope and porosity.

(b) Characteristics of Carbon Isotope. Carbonate rocks store organic and inorganic carbon dioxide. The lack or enrichment of carbon isotopes is caused by oxidizing or fermentation reactions or by deep-seated reducing heat fluid action; therefore, the $\delta^{13} \mathrm{C}$ value in carbonate minerals can indicate the carbon source [10].

Carbonate and organic carbon are the main carbon pool of sedimentary rocks and their average $\delta^{13} \mathrm{C}$ value varies from $1 \%$ to $-23 \%$, respectively. With regard to the isotopic composition characteristics, the carbon can have completely different origins. According to the above data, the proportion of organic carbon in the Jia-2 member of dolomite is low; that is, organic carbon is not included in the formation of carbonate deposits and diagenesis. The carbon isotope content of Jia- 2 member shows that the layers with high porosity have low values of carbon isotopes [11]. This value is lower than that of normal seawater and higher than that of fresh water, which is influenced by the atmospheric water and may be the result of the mixed water [12]. The layers with low porosity have a high value of carbon isotopes, likely due to the seepage reflux and evaporative pumping (Figure 11).

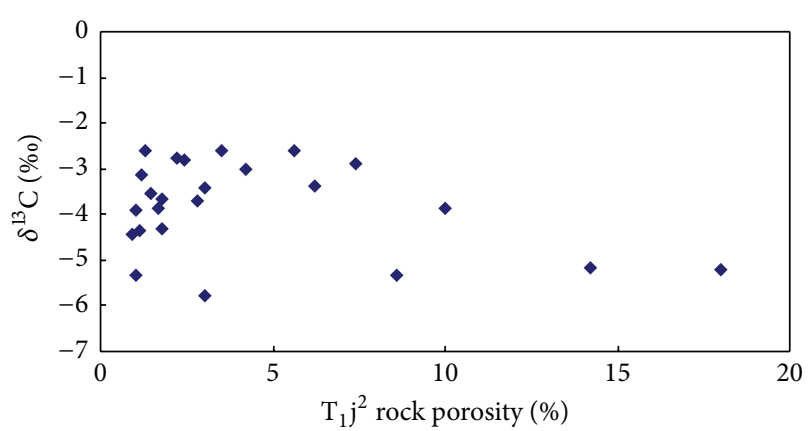

FIGURE 12: Relationship between carbon isotope and porosity.

Based on the basic lithological data, that is, grain dolomite $\rightarrow$ calcite dolomite $\rightarrow$ dolomicrite $\rightarrow$ gypsodolomite, the average value of $\delta^{13} \mathrm{C}$ has increased gradually, which reflects that the main body of rocks is controlled by evaporation and high salinity water (Table 2). The carbon isotope of the porous layer as well as the beach sediments is relatively light, which has a good correlation with the sedimentary environment.

(c) Characteristics of Oxygen Isotope. General characteristic shows that $\delta^{18} \mathrm{O}$ in dolomite is between -5.78 and $-2.61 \%$ o and the average is $-3.82 \%$, so the dispersion is not great, confirming the presence of a comparatively uniform sedimentary diagenetic environment [13]. Similar to the carbon isotope, the oxygen isotope in the high-pore layer is comparatively light but heavier than the atmospheric water, which indicates the influence of mixing water (Figure 12).

Thus, it can be said that mixing water dolomitization is very important in the formation of reservoirs; however, since it is influenced by the sedimentary environment in Jia-2 member, steady facies cannot always be observed. Therefore, not many regions and tectonics are completely dolomitized by mixing water. Only when the sedimentary environment is in the facies stage and can be dolomitized with mixing water can an effective reservoir come into being.

2.4. Dissolution. Dissolution is a very important constructive diagenesis for Jia-2 member, and it plays a very central role in the formation of the effective reservoir. Through the observation and analysis over large amounts of slices, it was found that the major dissolution in the third stage of the carbonate development, respectively, corresponds to the syngenetic diagenetic stage, the middle diagenetic stage, and the late diagenetic stage [14].

The first-stage dissolution mainly took place during the syngenetic stage with a close relation to the effect of the atmospheric water embodied as the bird's-eyes structures that are 


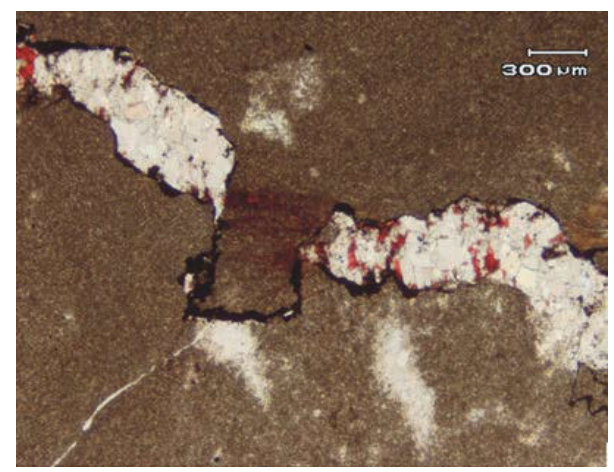

FIgure 13: Gypseous dolomicrite, S3, 2361.56 2361.72 $\mathrm{m}, \mathrm{T}_{1} \mathrm{j}^{2}$.

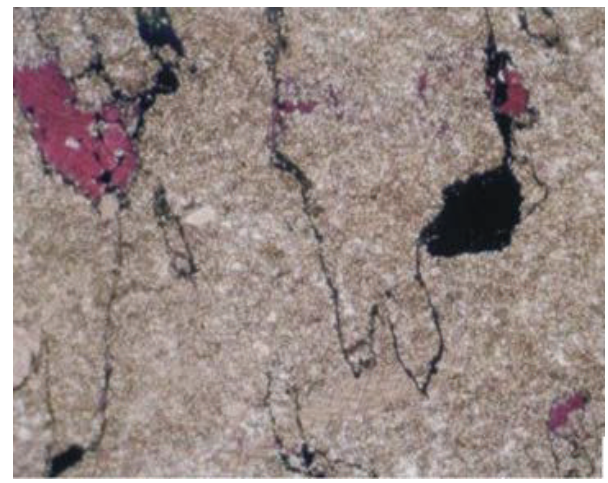

FIgURE 14: Silty dolomite, S2, 3648.94 3649.23 m, $\mathrm{T}_{1} \mathrm{j}^{2}$.

commonly developed in fine silty dolomite. Since the development took place very early, after a long buried diagenesis process, all the dissolution pores were almost filled with gypsum and calcite. Therefore, the first-stage dissolution does not contribute much to the carbonate reservoir in Jia- 2 member.

The second-stage dissolution took place during the middle diagenetic stage in a buried environment. The dissolution commonly took place along the stylolites and was closely related to the filling with organic matter (Figures 13 and 14). This kind of dissolution is quite common along the stylolites.

The third-stage dissolution is the most constructive diagenesis phase in the development of the carbonate reservoir. This dissolution phase set in comparatively late; therefore, almost all the dissolved pore space was reserved. The typical third-stage dissolution includes one of the fissures or calcite that had been filled with calcite or gypsum in early stages as well as the intracrystal pores in the coarse crystals dolomite.

2.5. Tectonic Disruption. The tectonic disruption is also a type of important constructive diagenesis for Jia-2 member, and there might be many formations of disruption and fissure. By analyzing large amounts of slices, two periods of tectonic disruption were found as indicators of significant differences in the filling due to the different time of the fissure formation. During first tectonic disruption stage, the fissures were developed with gypsum or filled with calcite. The tectonic disruption of the second stage took place comparatively late. The unfilled fissures can often be seen in the dissolved stylolites filled with organic matter. The fissures that occurred in this stage might be related to the tectonic uplifting in the late diagenetic stage in east Sichuan, which is of comparatively high opening and no obvious filling.

\section{The Formation and Evolution of the Reservoir}

According to the time sequence of different types of diagenesis stages and based on the detailed analysis of different slices, combined with the study area's burial evolution, the hydrocarbon evolution, and the maturity of organic matter, the diagenetic stages can be divided into syngenetic diagenetic stage, early diagenetic stage, middle diagenetic stage, and late diagenetic stage. The corresponding diagenetic environment and diagenetic fluid are of seawater-fresh water-mixing water, shallow burial environment, middle-deep burial stages, and middle-shallow burial stage (Figure 15).

The evolution history of diagenesis reflects the evolution history of reservoir pores. During the tectonic evolution of the area and the primitive sedimentary environment macrocontrol, the pore evolution of reservoirs is decided by the diagenetic types and syngenetic combination in different reservoirs [15].

From the diagenetic stages evolution history, it can be seen that Jia-2 member experienced multistage diagenesis with complicated and diverse diagenetic types.

In the syngenetic diagenesis, the rocks have a loose structure with large quantity pore water and weak compaction. The primary pore evolution includes intraparticle pores, interparticle pores, and skeleton pores. The syngenetic dolomite evolved into small amount of intracrystal pores. In the early diagenetic stage, the compaction was strengthened so the porous water was quickly expelled and the primary pores reduced clearly. When the burial depth increased, the compaction became even stronger and the early cementation took place, so the primary pore was dramatically reduced or even disappeared. The interparticle fluid dissolved along the contact surface of grains formed afterwards and compaction dissolution fissures. Some intracrystallization pores were formed as a result of mineral transformation and recrystallization. In the middle diagenetic stage, dolomite was developed and dissolution was strengthened so large amounts of intracrystal pores and various secondary pores appeared, including interparticle pores, intraparticle pores, and intercrystal pores, which made up good reservoir space. At the latest diagenetic stage, the base of secondary pore development in early and middle diagenetic stages, the dissolution was further enlarged to form some moldic pores and superlarge pores. At the same time, the tectonic fractures developed in many stages, spread in the shape of reticula, and finally formed dolomite of high porosity.

\section{Conclusion}

(1) The main diagenesis types of carbonate rocks in the research area include compaction, cementation, pressure solution, dolomitization, recrystallization, 


\begin{tabular}{|c|c|c|c|c|c|}
\hline Diagenetic stage & \multicolumn{2}{|c|}{ Syngenetic } & Early & Middle & Late \\
\hline Diagenetic environment & $\begin{array}{c}\text { Meteoric } \\
\text { environment }\end{array}$ & $\begin{array}{c}\text { Mixing } \\
\text { zone }\end{array}$ & $\begin{array}{c}\text { Shallow } \\
\text { burial }\end{array}$ & $\begin{array}{c}\text { Deep } \\
\text { burial }\end{array}$ & $\begin{array}{c}\text { Middle } \\
\text { burial }\end{array}$ \\
\hline Hydrocarbon evolution & No hydrocarbon & Biogas & Oil & Gas \\
\hline Organic maturation & Immature & Half-matured & Mature & Overmature \\
\hline & & & \\
\hline
\end{tabular}

\footnotetext{
Improve the reservoir properties

Reduce the reservoir porosity

Small effect on porosity
}

FIGURE 15: Characteristics of diagenetic evolution.

dissolution, and tectonic disruption. Among them, cementation, dissolution, dolomitization, and recrystallization contribute greatly to the porosity development of reservoirs.

(2) Reservoir has experienced four stages, including syndiagenetic stage, early stage of diagenesis, diagenetic stage, and the late diagenetic stage. Most of the primary pores in the diagenetic evolution reservoir have been destroyed, and, at present, the pores mainly belong to the category of secondary pores.

\section{Competing Interests}

The authors declare that they have no competing interests.

\section{References}

[1] Y. Wang, "Geochemical characteristics of dolomites in lower triassic feixianguan formation, Northeast Sichuan, China," Acta Sedimentologica Sinica, vol. 27, no. 6, pp. 1043-1049, 2009 (Chinese).

[2] X. F. Zhang, H. Wenxuan, Z. Juntao et al., "Geochemical analyses on dolomitizing fluids of Lower Ordovician carbonate reservoir in Tarim basin," Earth Science Frontiers, vol. 15, no. 2, pp. 80-89, 2008 (Chinese with English abstract).
[3] I. S. Al-Aasm, "Chemical and isotopic constraints for recrystallization of sedimentary dolomites from the Western Canada Sedimentary Basin," Aquatic Geochemistry, vol. 6, no. 2, pp. 227$248,2000$.

[4] L. S. Land, "The isotopic and trace element geochemistry of dolomite: the state of the art," International Journal of Modern Physics A, vol. 19, no. 5, pp. 459-477, 1980.

[5] M. Coniglio, Q. Zheng, and T. R. Carter, "Dolomitization and recrystallization of middle Silurian reefs and platformal carbonates of the Guelph Formation, Michigan Basin, southwestern Ontario," Bulletin of Canadian Petroleum Geology, vol. 51, no. 2, pp. 177-199, 2003.

[6] R. C. Zheng, L. Dang, C. Zheng, H. Wen, G. Zhou, and F. $\mathrm{Xu}$, "Diagenetic system of carbonate reservoir in Huanglong Formation from East Sichuan to North Chongqing area," Acta Petrolei Sinica, vol. 31, no. 2, pp. 237-245, 2010 (Chinese).

[7] D. G. Green and E. W. Mountjoy, "Fault and conduit controlled burial dolomitization of the Devonian west-central Alberta Deep Basin," Bulletin of Canadian Petroleum Geology, vol. 53, no. 2, pp. 101-129, 2005.

[8] J. Kaufman, G. N. Hanson, and W. J. Meyers, "Dolomitization of the devonian swan hills formation, Rosevear field, Alberta, Canada," Sedimentology, vol. 38, no. 1, pp. 41-66, 1991.

[9] B. Capaccioni, M. Didero, C. Paletta, and P. Salvadori, "Hydrogeochemistry of groundwaters from carbonate formations with 
basal gypsiferous layers: an example from the Mt CatriaMt Nerone ridge (Northern Appennines, Italy)," Journal of Hydrology, vol. 253, no. 1-4, pp. 14-26, 2001.

[10] B. Q. Wang, Z. T. Qiang, F. Zhang et al., "Isotope characteristics of dolomite from the fifth member of the Ordovician Majiagou Formation, the Ordos basin," Geochimica, vol. 38, no. 5, pp. 472479, 2009 (Chinese with English Abstract).

[11] B. Capaccioni, M. Didero, C. Paletta, and L. Didero, "Saline intrusion and refreshening in a multilayer coastal aquifer in the Catania Plain (Sicily, Southern Italy): dynamics of degradation processes according to the hydrochemical characteristics of groundwaters," Journal of Hydrology, vol. 307, no. 1-4, pp. 1-16, 2005.

[12] S. J. Huang, K. K. Huang, J. Lü, and Y. F. Lan, "Carbon isotopic composition of Early Triassic marine carbonates, Eastern Sichuan Basin, China," Science China Earth Sciences, vol. 55, no. 12, pp. 2026-2038, 2012.

[13] L. Xiong, Study on the Relationship between Reservoirs Rocks Characteristics and Sedimentary-Diagenesis Evolution of Triassic Jialingjiang Formation in Sichuan Basin, Chengdu University of Technology, 2011 (Chinese).

[14] R. Wierzbicki, J. J. Dravis, I. Al-Aasm, and N. Harland, "Burial dolomitization and dissolution of Upper Jurassic Abenaki platform carbonates, Deep Panuke reservoir, Nova Scotia, Canada," AAPG Bulletin, vol. 90, no. 11, pp. 1843-1861, 2006.

[15] C. H. Moore, Carbonate Diagenesis and Porosity, Elsevier, New York, NY, USA, 1989. 

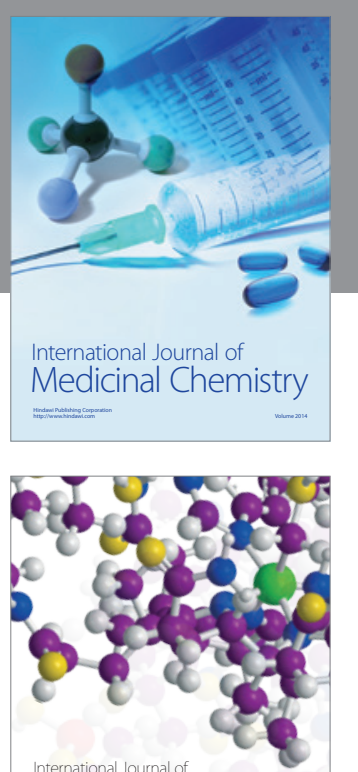

Carbohydrate Chemistry

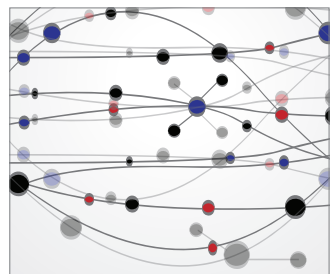

The Scientific World Journal
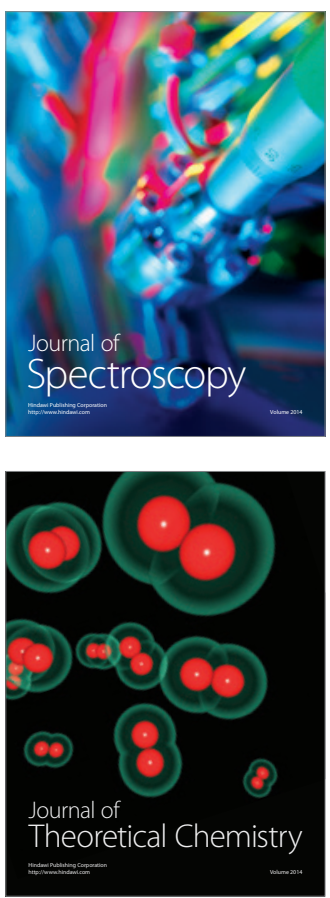
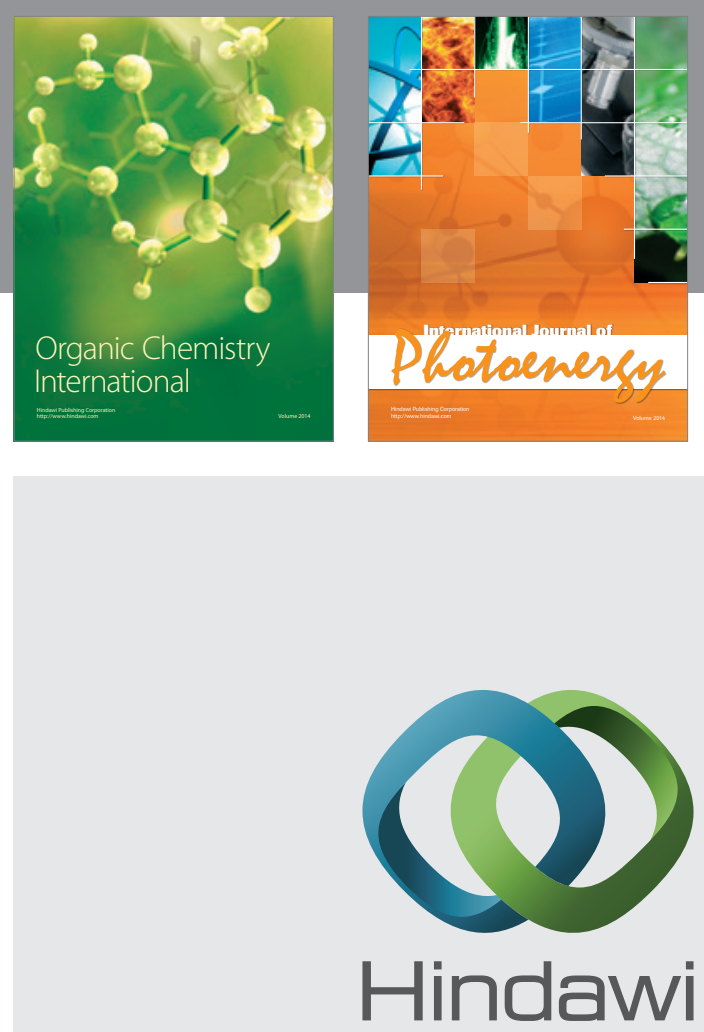

Submit your manuscripts at

http://www.hindawi.com

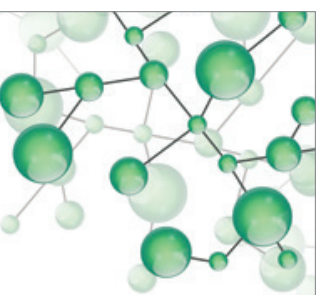

International Journal of

Inorganic Chemistry

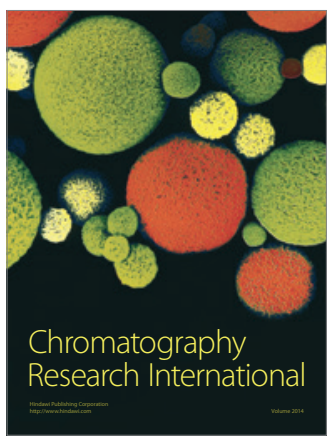

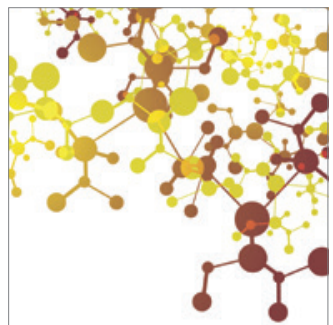

Applied Chemistry
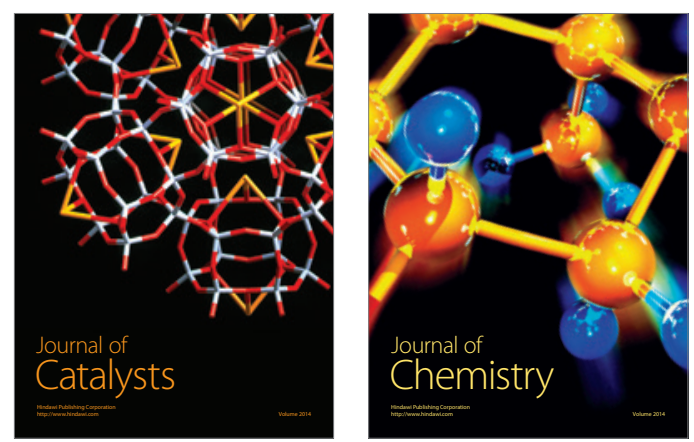
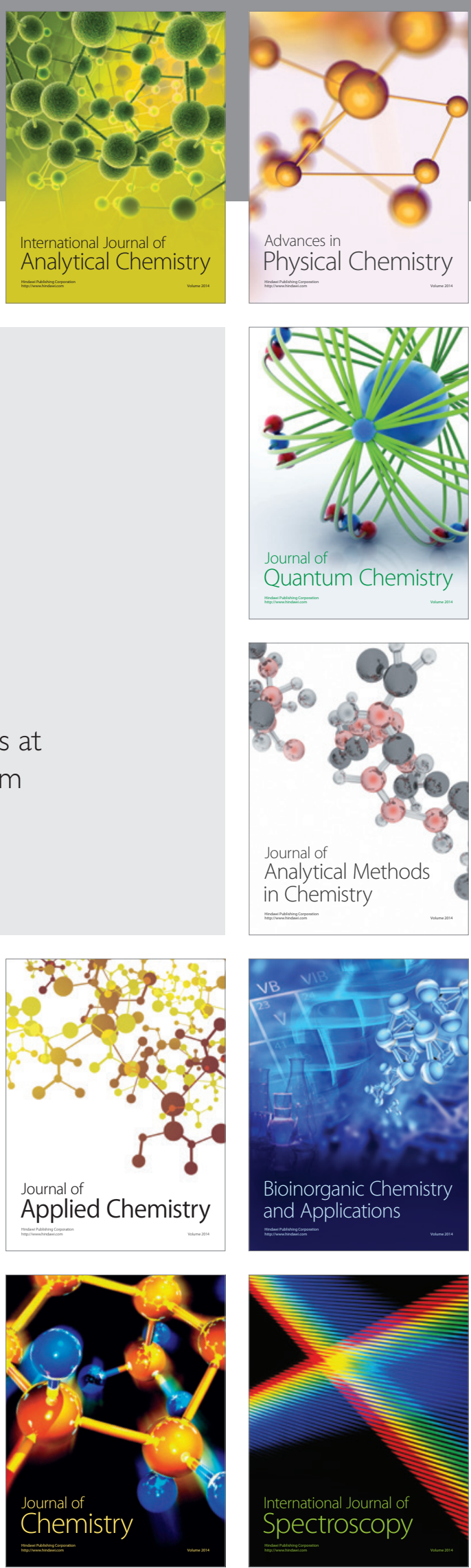